\title{
Social governance of villages at the basic level under big data
}

\author{
Li Yongcai \\ CPC Shiyan Municipal Party School, Shiyan, Hubei, China, 442000
}

Keywords: big data; rural governance; social system; primary level management

Abstract: The country's development depends on common progress of cities and villages. On the road of social construction in the new era, the country pays more attention to the governance of villages at the basic level. To perform the social governance of villages at the basic level under big data, it's necessary for basic-level leaders to establish the correct values, to improve the moral quality of villagers and coordinate rural social relations. Only by doing this can we build a social security governance and promote the collective development of rural collectives.

\section{Introduction}

Social governance is an important goal of national development. The development of a country and the inheritance of a nation not only depends the speed of economic development, but also the construction of social and spiritual values. Rural social governance is not only a matter of state leaders, but also a matter of rural leadership at basic-level. Social governance is a comprehensive and systematic cultural system. In the context of big data, basic rural social governance requires both the attention of the state and the investment of funds. It also requires the active participation of rural leaders at basic-level. In the process of implementing the rural social security governance system, all villagers are required to take the joint establishment of a civilized village as target. Under the background of big data, it's difficult for basic-level leaders to establish the correct values, to improve the moral quality of villagers and coordinate rural social relations, which is also one of the problems faced by basic rural social governance. Since the reform and opening up, in order to stimulate the enthusiasm and creativity of the villagers, the villager autonomy system has been established, in order to enable the villagers to carry out self-management of production and life, so as to achieve the goal of social security governance in an all-round way [1].

\section{Establishment of the correct values for basic-level leaders}

The development of society is inseparable from the construction of spiritual civilization. According to big statistics, there are still many rural towns in China. Although the village is not so easy to control as the city, the development of rural spiritual civilization cannot be slack. Establishing the correct values of the people is also an important task of basic rural social governance. Rural leaders at basic-level also play an important role in social governance. The basic definition of social governance should be carried out from the aspects of spiritual civilization 
construction and social security. Cultivating the sense of responsibility of the people and supervising the environmental remediation are all important tasks of social governance. Social governance is not only the relationship between people and people, but also the improvement of the relationship between man and nature. On the road of rural social governance, rural leaders at basiclevel have a long way to go. From the perspective of leadership, the primary task of strengthening rural social governance is to deepen the basic leadership management system and strengthen basic leadership functions, because strengthening basic management is the cornerstone of social governance [2].

The healthy development of the whole society of China is the central goal of the leader, and the social governance of the countryside cannot be ignored. In the process of rural governance, strengthening basic leadership management and establishing correct values are of great significance for leading the work of the whole village, and are also very important in the future social governance process. In the process of rural social governance, rural leaders at basic-level should open up the rural areas, strengthen market management, and deepen the contents of some social security management. Because, to a certain extent, the correct values of rural leaders at basic-level should be focused on cultivating and establishing. Due to the continuous progress of rural development economic reform and opening up, it is followed that the Western thoughts are gradually deepening into the rural area, so the state of consciousness of the people is slowly changing. There are also many problems in the process of social governance. Strenghtening the cultivation of local government functional departments for the values of rural leaders at basic-level, providing necessary financial support and policy guidance for rural construction, cultivating the consciousness of rural leading cadres, and giving the rural leadership structure ample room for development are the key to improve social governance. While establishing the correct organizational values of rural leadership at basic-level, the formulation of rural management systems plays a crucial role in rural social governance. The institutional theory of village is widely used in the social governance of villages and towns. The specific operation is shown in Figure 1:

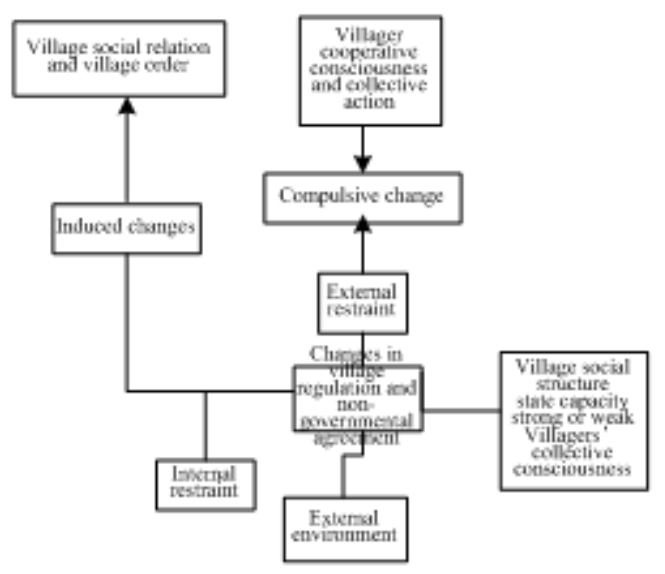

Figure 1. Application of institutional theory in village governance

It can be seen from Figure 1 that the construction of the relationship between village leaders and villagers and the formation of a management system are of great significance for the proper governance of the society. Because there is an important connection between the diverse rural social development phenomenon and the village collective, it is very important to establish correct values to promote the village collective economy and social security governance [3].

\section{Improvement of the moral quality of villagers}

To achieve the goal of safe governance, social governance must pay more attention to the 
improvement of the moral quality of the villagers. The rural collectives under big data need to be built together. At present, the existing forms of rural areas cannot develop into urbanized community life. Establishing the basic rural social governance programs to undertake rural social governance functions, the program is planned with development concept, in the process of improving the overall quality of rural people, there is a long way to go [4]. In order to improve the moral quality of the rural people, we can strengthen the building of spiritual civilization and strengthen the cultural input of rural people. Because there are many "literacy" phenomena in rural areas under normal circumstances, these phenomena limit the progress of social security development to some extent. Because the correct policy needs correct guidance and advancement, strengthening the villagers' cultural construction and cultivating moral quality are the primary tasks of the social leaders in the new era. In this task, the party and the state need provide strong support and financial assistance. It is possible to build a cultural atmosphere by subscribing to textbooks and other measures, and to formulate some programs to regulate the behavior of villagers. This is also important for the rural people to improve their moral quality. In the process of improving the overall quality of rural people, it is inevitable to formulate some civil regulations to determine the basic relationship with rural social governance. The specific framework is shown in Figure 2:

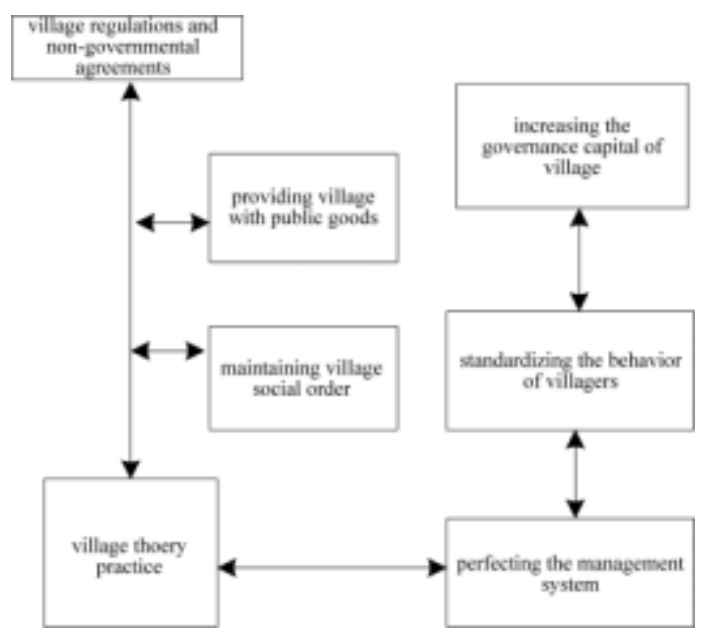

Figure 2. Basic relation between village regulations and non-governmental agreements and village governance

It can be clearly seen from Figure 2 that in the process of formulating the village regulations, it is necessary to add elements that supply rural public goods and maintain rural social order, which contributes to the theory and practice of rural social security governance, so as to improve the management system, and then regulate the behavior of villagers and improve the rural social security governance capital [5].

\section{Coordination of rural social relations}

Coordinating various social relations in rural areas is also an important part of building a rural social governance system. It is important to regulate the role of various social relationships in regulating the social composition of villagers. Generally, it is generally determined whether the rural social relations are properly categorized through questionnaires, and whether there is the village regulations, what's the type of village regulations and the role of village rules and regulations in rural grassroots leadership. In this situation, the villagers' questionnaire survey statistics are conducted. The village rules and regulations collected under the big data are in the perspective of the people's vision. The results are shown in Table 1. 
Table 1. Whether there is the village regulations

\begin{tabular}{ccc}
\hline $\begin{array}{c}\text { Whether there is the } \\
\text { village regulations in } \\
\text { eyes of villagers }\end{array}$ & $\begin{array}{c}\text { Statistics } \\
\text { number }\end{array}$ & Proportion \\
\hline Yes & 203 & $42.85 \%$ \\
No & 196 & $33.27 \%$ \\
No idea & 152 & $22.19 \%$ \\
\hline
\end{tabular}

It can be seen from the data in Table 1 that $42.85 \%$ of the villages surveyed have written village regulations, $33.27 \%$ of the villages have no village rules, and $22.19 \%$ of the villagers have no idea about the documents of village regulations. This shows that in the work of rural social governance, we must strengthen the cognitive ability of the people, integrate various social relations, and break down the problematic groups one by one to achieve common development and progress in various social relations [6].

The basic rural leadership organization structure plays a leading role in rural governance. Balancing rural social relations helps to build the credibility of rural workers at basic-level. In people's impressions, rural workers at basic-level may have corruption, which is one of the main problems in rural social governance. Therefore, the elimination of corruption is also an important task in coordinating various social relations in the countryside. The basic leadership organization structure of the village must be people-oriented in the management of the villagers and meet the fundamental interests of the majority of the villagers. Balancing the relationship between the interests of the villagers and the ecological environment, and promoting the relationship between agricultural development and the market, these issues are all guided by the basic rural leadership organization structure. In the process of promoting social governance, it also requires a large amount of financial investment, which is very important for building the spiritual culture of the villagers and balancing the common relations of the whole society. The social security governance of village can be completed only by promoting the overall progress of the social relation of village. Combined with the proportion of amount invested by country for village cultural development in total financial expenditure for several years, a graph as Figure 3 can be drawn:

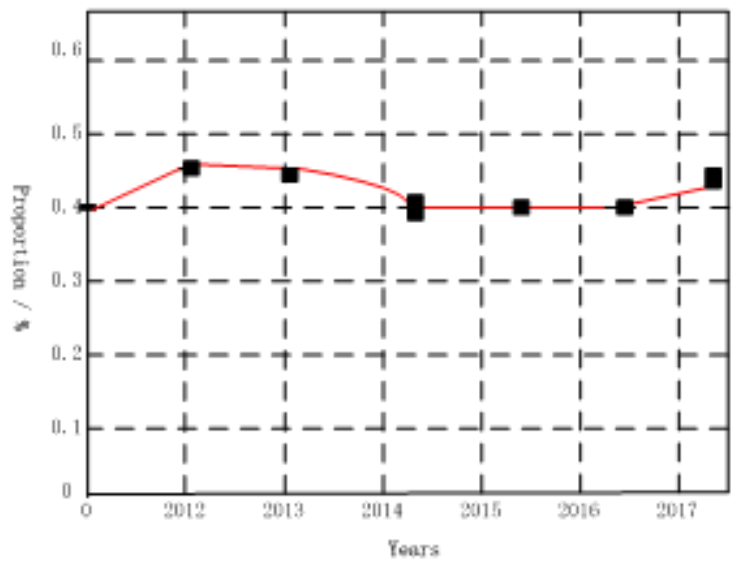

Figure 3. Proportion of cultural undertakings in fiscal expenditures over the years

It can be seen from the data in Figure 3 that the proportion of rural cultural construction expenditure to fiscal expenditure is relatively large, and it has been in a stable state. This indicates that in the process of social security governance, the state has always paid attention to balancing social relations, caring about the cultural construction of villagers, and making the various social 
relations in rural areas develop together [7].

\section{Conclusion}

In the process of basic rural social governance, it's necessary to cultive the multi-subjective power of village society and villager, introduce the consciousness of deliberative democracy into social governance of village, promote a positive interaction between social relation of villager and villager order, protect the interests of villager leaders at basic-level and villagers to achieve the civil social governance of village.

\section{References}

[1] HUANG Lin. How to Promote the Innovation of Social Governance in Big Data Era [J]. People's Tribune, 2018(9):68-69.

[2] LI Xia. Relying on Big Data to Achieve Refined Social Governance [J]. People's Tribune, 2018(9):70-71.

[3] LI Bacui. Innovation of Basic Social Governance in Big Data Era [J]. Management Observer, 2016, 65(14):32-34.

[4] TAN Shizan. Innovation Trend of Basic Social Governance in Big Data Era [J]. Chongqing Administration (Public Forum), 2016, 48(4):57-59.

[5] WANG Huahua. Research on the Social Governance Capability of Rural Party Organizations in the Age of Big Data_Information Fission and Co-governance [J]. Theory and Reform, 2017, 43(5):119-129.

[6] YANG An. Big Data and Social Governance Innovation [J]. Observation and Ponderation, 2017, 45(3):45-50.

[7] YANG Jie, SHI Zhibin, LIU Zhongbao. Simulation Research on Fast Acquisition of End User Information under Big Data Analysis [J]. Computer Simulation, 2018, 35(02):441-445. 